\title{
20. INTERSTITIAL WATER CHEMISTRY: DEEP SEA DRILLING PROJECT, LEG $\mathbf{8}^{1}$
}

\author{
B. J. Presley ${ }^{2}$ and I. R. Kaplan, Department of Geology and Institute of Geophysics \\ and Planetary Physics, University of California, Los Angeles, California
}

\section{INTRODUCTION}

The interstitial water received at UCLA from Leg 8 (Hawaii to Tahiti) consisted of nineteen samples of approximately 5 milliliters each, four samples of approximately 10 milliliters each, and four samples of approximately 100 milliliters each. These pore waters had been squeezed from sediments consisting primarily of biogenic ooze, and had been collected at five different drilling sites along the route.

All water was filtered through a 0.45 -micron membrane filter immediately after squeezing. The 5 -milliliter samples were sealed in plastic syringes, and were kept refrigerated except for the time in shipment to UCLA from SIO. The 100-milliliter samples were also refrigerated, but were stored in plastic bottles. The 10-milliliter samples were frozen in polyethylene bottles on board ship, and were kept frozen until analysis had begun.

Analysis was started as soon as the samples had arrived at UCLA; nevertheless, as much as three months had then elapsed since collection.

\section{EXPERIMENTAL PROCEDURES}

The analytical procedures currently being used in the UCLA interstitial water program are described elsewhere (Presley, Leg 7 report; Presley and Claypool, Leg 7 report). These procedures have evolved during the course of the Deep Sea Drilling Program, as a result of attempts to obtain more and better data from the small samples available.

Although the procedures used for the Leg 8 samples are not exactly the same as those described in the references given above, most changes are too minor to warrant mention. These samples provided the first opportunity for use of a special manometer for measuring carbon dioxide volumes, as described by Presley and Claypool. This device has greatly increased the precision of the carbon dioxide measurement, and it is hoped it will lead to better agreement among the groups measuring carbon dioxide.

\footnotetext{
${ }^{1}$ Publication No. 890 Institute of Geophysics \& Planetary Physics.

${ }^{2}$ Present address: Department of Oceanography, Texas A \& M University, College Station, Texas.
}

\section{RESULTS AND DISCUSSION}

The data obtained from the 5-milliliter samples are presented in Table 1, but major cation concentrations have been omitted, because these can be found in the report by Manheim, et al (this volume). Data obtained from the 100-milliliter and from the frozen samples can be found in Table 2 .

The trace metals iron, cobalt, nickel and copper can only be determined on relatively large volume samples by our present techniques, and these are limited to four or fewer in number for each leg by a directive from the Deep Sea Drilling Project Interstitial Water Panel. The four samples collected on Leg 8 showed concentrations somewhat similar to those found in the biogenic oozes from Legs 6 and 7, except for the very high iron values found at Sites 69 and 73 and the high copper value at Site 73 .

The significance of these high trace element concentrations is difficult to assess when so few samples are available for analysis, and when sampling and shipboard handling can introduce serious contamination. It is interesting to note, however, that previous preliminary hole summaries have contained specific mention of sediment contamination by rust from the drill pipe, yet water squeezed from these sediments has not been enriched in iron or other trace metals. Perhaps, then, contamination during sampling is not actually a serious problem.

The Leg 8 sediment, which gave pore water rich in dissolved iron, is a radiolarian ooze-a sediment which would be expected to be poor in total iron in the solid phase. The highest concentration of dissolved iron in samples from previous legs was also found in radiolarian oozes, although not all such oozes have given high dissolved iron. It thus seems that under some conditions these sediments release iron, but there is no obvious relationship to $\mathrm{Eh}, p \mathrm{H}$ or other measured variables.

The high iron sample from Hole 73 was also high in copper and nickel, but low in manganese, once again confirming previous observations that manganese concentrations are independent of those of other trace metals measured. The manganese concentration is highly variable, as it has been in previous samples, and there is no indication of why this should be so. For 
TABLE 1

Selected Major and Minor Constituents and $\delta \mathrm{C}^{13}$, Interstitial Water, DSDP, Leg 8

\begin{tabular}{|c|c|c|c|c|c|c|c|c|c|c|c|}
\hline $\begin{array}{l}\text { Sample }^{\mathrm{a}} \\
\text { Number }\end{array}$ & $\begin{array}{l}\text { Depth }^{\mathrm{b}} \\
(\mathrm{m})\end{array}$ & Age & Description of Sediments & $\underset{(\mathrm{g} / \mathrm{kg})}{\mathrm{C} 1}$ & $\underset{(\mathrm{mg} / \mathrm{kg})}{\mathrm{Br}}$ & $\underset{(\mathrm{mg} / \mathrm{kg})}{\mathrm{B}}$ & $\underset{(\mu \mathrm{g} / \mathrm{kg})}{\mathrm{Mn}}$ & $\begin{array}{c}\Sigma \mathrm{CO}_{2} \\
(\mathrm{mM} / \mathrm{kg})\end{array}$ & $\begin{array}{l}\Sigma \mathrm{CO}_{2}{ }^{\mathrm{c}} \\
(\mathrm{mM} / \mathrm{kg})\end{array}$ & $\begin{array}{c}\delta \mathrm{C}^{13} \\
\left(\Sigma \mathrm{CO}_{2}\right)\end{array}$ & $p \mathrm{H}^{\mathrm{d}}$ \\
\hline $69.0-3-3$ & 28 & Middle Miocene & Light orange radiolarian ooze, nannofossil bands & 19.9 & 75 & 6.4 & $<50$ & 3.01 & - & -2.70 & 7.08 \\
\hline $69.0-5-3$ & 122 & Lower Oligocene & Light yellow-brown radiolarian nannofossil ooze & 19.8 & 74 & 6.3 & 640 & 2.71 & 2.32 & -0.88 & 7.70 \\
\hline $69 A-8-6$ & 143 & Lower Oligocene & White nannofossil radiolarian ooze & 19.7 & 70 & 5.6 & 680 & 2.78 & 2.87 & -0.75 & 7.69 \\
\hline $69.0-6-4$ & 193 & Middle Eocene & White radiolarian ooze & 20.0 & 73 & 6.1 & 1175 & 2.70 & 2.73 & -1.13 & 7.64 \\
\hline $70.0-3-1$ & 18 & Upper Miocene & Dark gray mottled radiolarian ooze & 19.7 & 65 & 5.1 & 310 & 2.81 & 2.66 & -0.98 & 7.64 \\
\hline $70 A-7-4$ & 174 & Middle Oligocene & Light gray-green radiolarian nannofossil ooze & 19.7 & 76 & 5.1 & 390 & 2.20 & 1.57 & +0.44 & 7.32 \\
\hline $70 \mathrm{~A}-15-2$ & 241 & Middle Oligocene & Light gray-green radiolarian nannofossil ooze & 19.9 & - & 5.4 & 1225 & 1.40 & 4.37 & - & 7.27 \\
\hline $71.0-2-3$ & 5 & Upper Pliocene & $\begin{array}{l}\text { Interbedded foraminiferal-radiolarian-nannofossil } \\
\text { ooze }\end{array}$ & 20.0 & 78 & 6.7 & 810 & 2.73 & 2.70 & -1.02 & 7.66 \\
\hline $71.0-14-3$ & 120 & Middle Miocene & Light gray radiolarian-nannofossil ooze & 20.1 & - & 6.8 & $<50$ & 2.76 & 2.73 & -0.29 & 7.44 \\
\hline $71.0-28-2$ & 248 & Lower Miocene & Light gray foramineferal-nannofossil ooze & 19.8 & 70 & - & $<50$ & 2.70 & 2.70 & +0.63 & 7.35 \\
\hline $71.0-48-2$ & 430 & Upper Oligocene & Gray-green nannofossil chalk, ash zone & 20.2 & 77 & - & $<50$ & 1.57 & 1.70 & -0.57 & - \\
\hline $72 \mathrm{~A}-2-3$ & 22 & Pliocene & $\begin{array}{l}\text { Well-bedded radiolarian and nannofossil-radiolarian } \\
\text { ooze }\end{array}$ & - & - & 5.8 & 3125 & 2.93 & 3.17 & -1.23 & 7.60 \\
\hline $72.0-4-4$ & 156 & Middle Miocene & Light green nannofossil ooze & 19.6 & 72 & 5.9 & $<50$ & 3.50 & 3.38 & +0.98 & 7.54 \\
\hline $72.0-5-6$ & 220 & Lower Miocene & Light green nannofossil ooze & 20.1 & 71 & - & $<50$ & 3.56 & 3.51 & +0.78 & 7.52 \\
\hline $72.0-7-4$ & 318 & Middle Oligocene & White nannofossil ooze, foraminifera & 20.1 & 68 & 5.9 & $<50$ & 3.14 & 3.38 & +0.18 & 7.52 \\
\hline $73 \cdot 0-2-3$ & 9 & Pleistocene & Banded siliceone-carbonate ooze & 19.5 & 64 & 5.5 & 210 & 2.99 & 3.00 & -0.65 & 7.69 \\
\hline $73.0-12-3$ & 145 & Lower Miocene & Radiolarian-nannofossil chalk ooze & 19.5 & - & 6.2 & 210 & 3.12 & 3.27 & +0.18 & 7.64 \\
\hline $73.0-16-3$ & 267 & Lower Oligocene & White radiolarian-nannofossil ooze & 19.9 & 70 & 5.5 & $<50$ & 2.64 & 2.86 & +2.15 & 7.00 \\
\hline $73.0-20-5$ & 299 & Upper Eocene & Mottled radiolarian nannofossil chalk ooze & 19.8 & 71 & 6.7 & 50 & 3.11 & 3.27 & - & 7.68 \\
\hline \multicolumn{4}{|c|}{ Surface Sea Water } & 19.37 & 67 & 4.5 & 2 & 2.60 & 2.60 & 0 & 8.20 \\
\hline
\end{tabular}

${ }^{\mathrm{a}}$ Hole, core and sections.

${ }^{b}$ Depth below sediment-water interface.

${ }^{\mathrm{c}}$ Data from UCLA gas chromatograph on board ship.

$\mathrm{d}_{\text {Shipboard data. }}$ 
TABLE 2

Trace Constituents of Interstitial Water, Deep Sea Drilling Project, Leg 8

From Large Volume $(\approx 100 \mathrm{ml})$ Samples

\begin{tabular}{lcccccccc}
\hline $\begin{array}{c}\text { Sample } \\
\text { Number }\end{array}$ & $\begin{array}{c}\mathrm{Depth}^{\mathrm{a}} \\
(\mathrm{m})\end{array}$ & $\begin{array}{c}\mathrm{Fe} \\
(\mu \mathrm{g} / \mathrm{kg})\end{array}$ & $\begin{array}{c}\mathrm{Co} \\
(\mu \mathrm{g} / \mathrm{kg})\end{array}$ & $\begin{array}{c}\mathrm{Ni} \\
(\mu \mathrm{g} / \mathrm{kg})\end{array}$ & $\begin{array}{c}\mathrm{Cu} \\
(\mu \mathrm{g} / \mathrm{kg})\end{array}$ & $\begin{array}{c}\mathrm{Mn} \\
(\mathrm{mg} / \mathrm{kg})\end{array}$ & $\begin{array}{c}\mathrm{Si}^{\mathrm{b}} \\
(\mathrm{mg} / \mathrm{kg})\end{array}$ & $\begin{array}{c}\mathrm{PO}_{4}{ }^{\mathrm{b}} \\
(\mathrm{mg} / \mathrm{kg})\end{array}$ \\
\hline $69 \mathrm{~A}-10-4$ & 159 & 220 & 4.0 & 24 & 14 & 1.200 & 25.7 & 0.1 \\
$73-20-3$ & 298 & 210 & 3.0 & 35 & 79 & 0.070 & 28.5 & 25.6 \\
$74-12-2$ & 101 & 20 & 1.0 & 16 & 13 & 0.050 & 10.6 & 4.5 \\
$75-9-6$ & 82 & 4 & 2.0 & 4 & 3 & - & 7.2 & 2.1 \\
SEAWATER & 0 & 10 & 0.1 & 2 & 3 & 0.002 & 3.0 & - \\
\hline
\end{tabular}

${ }^{\mathrm{a}}$ Depth below sediment-water interface.

${ }^{b}$ Determined on a separate aliquot, kept frozen until analyzed.

example, the lithology of squeezed samples at Site 72 seems to be relatively constant, as is the $p H$, dissolved carbonate, and other variables measured, yet, the dissolved manganese varies from 50 to $3000 \mathrm{ppb}$.

Boron concentrations in the present samples tend to be somewhat higher than is typical of seawater, but there is no evidence for either contributions by emanations from depth, or uptake by clays during diagenesis.

The chloride and bromide values are in all cases close to those typical of seawater, although some samples seem to be enriched in both by a few per cent. This enrichment, and the scatter in the data is most likely the result of evaporation during storage and handling of samples; that is, both of these elements are relatively inert to diagenetic changes occurring in the sediment column. Only where there is evidence of the presence of evaporites, such as in the Gulf of Mexico, have we found chloride and bromide concentrations significantly different from those of the overlying seawater.

The first column of total carbon dioxide values $\left(\Sigma \mathrm{CO}_{2}\right)$ given in Table 1 were obtained by laboratory manometric measurement of the carbon dioxide evolved from an acidified sample of water. The small sample size can lead to analytical problems, but we believe our present system has solved most of these. The coefficient of variation on replicate samples of typical size is about 1 per cent, and bicarbonate standards also give the expected volumes of carbon dioxide to within 1 per cent. It can be seen that there is moderately good agreement, with a few exceptions, between our laboratory values and the values from the shipboard gas chromatograph (Table 1). The shipboard determination is made using only 0.2 milliliter of water; therefore, analytical scatter is difficult to avoid. Considering the difficulties in this measurement, the \pm 10 per cent agreement shown by most samples is as good as can be expected. There is a serious discrepancy in the values for the deepest sample from Site 70, but there is no way to choose between the two values at this time.

As can be seen from Table 1, most of the Leg 8 interstitial waters proved to be somewhat enriched in carbon dioxide compared to normal seawater, but the enrichments were slight. Samples from previous legs have often shown a tendency for depletion of carbon dioxide at depth, and this can be seen at Sites 70 and 71. The concentration at other Leg 8 sites is relatively constant with depth, however, and the factors necessary to cause a carbon dioxide depletion, probably by carbonate precipitation, are unknown.

The $\mathrm{C}^{13} / \mathrm{C}^{12}$ ratios of the total dissolved carbonate from the Leg 8 samples, like those from Leg 7, show relatively minor variation with depth and position, compared to the large isotopic variations found in interstitial water from near-shore sediments by Presley and Kaplan (1968). These authors show how biological degradation of organic matter continues after burial, leading to an increase in total dissolved carbonate and a lowering of the $\mathrm{C}^{13} / \mathrm{C}^{12}$ ratio.

The $\delta \mathrm{C}^{13}$ of the Leg 8 interstitial water carbonate carbon is generally somewhat lower than the +0.5 per cent characteristic of deep ocean water (Deuser and 
Hunt, 1968) except for a few samples from below 100 meters depth in the sediment column. This seems to indicate a small but measurable contribution of carbon dioxide from oxidizing organic matter, a conclusion which is consistent with the slight enrichment in dissolved carbonate shown by most samples. It is probably unrealistic to place much significance on small changes in the isotope ratio with depth, in view of the possibilities of contamination or fractionation of the small samples during handling. Nevertheless, variations do occur, and perhaps as more samples are analyzed, a pattern will develop.

\section{REFERENCES}

Deuser, W. G. and Hunt, J. M., 1969. Stable isotope ratios of dissolved inorganic carbon in the Atlantic. Deep Sea Res. 16, 221.
Presley, B. J., (1971). Techniques for analyzing interstitial water samples. Part I: determination of selected minor and major inorganic constituents. In Winterer, E. L., et al., 1971. Initial Reports of the Deep Sea Drilling Project, Volume VII. Washington (U. S. Government Printing Office) in press.

Presley, B. J. and Claypool, G. E., 1971. Techniques for analyzing interstitial water samples. Part II: determination of total dissolved carbonate and carbon isotope ratios. In Winterer, E. L. et al., 1971. Initial Reports of the Deep Sea Drilling Project, Volume VII. Washington (U. S. Government Printing Office) in press.

Presley, B. J. and Kaplan, I. R., 1968. Changes in dissolved sulfate, calcium and carbonate from interstitial water of near-shore sediments. Geochim. Cosmochim. Acta. 32, 1037. 